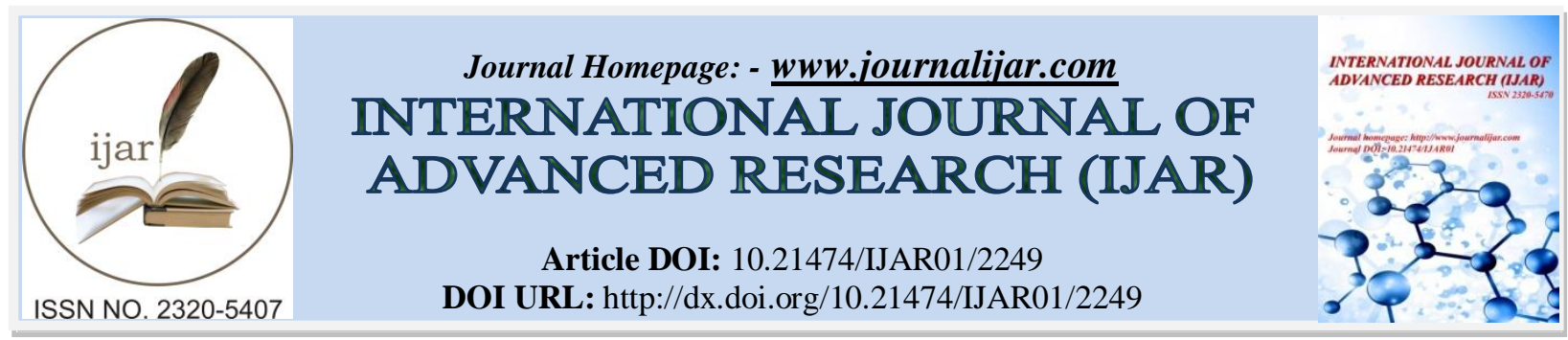

RESEARCH ARTICLE

\title{
ETHNOBOTANICAL USE OF PLANT IN ALIGARH DISTRICT (U.P.) FOR TREATING THE SOME COMMON DISEASES.
}

Yogendra singh.

Department of Botany, Divya Nand Vidyamandir Maha vidyalaya, Sandila, Hardoi.

\section{Manuscript Info}

\section{Manuscript History}

Received: 29 September 2016

Final Accepted: 30 October 2016

Published: November 2016

Key words:-

Aligarh district, Ethnobotany,

Ethnomedicine, Medicinal plant.

\begin{abstract}
Ethnobotany is the study of how people of a particular culture and region make use of indigenous plants. The importance of medicinal plants in traditional healthcare practices, providing clues to new areas of research and in biodiversity conservation is now well recognized. However, Ethnobotanical information's on the medicinal plants were lacking from many interior areas of Aligarh district (U.P.). The present paper provided these informations related 62 plant species belonging to 35 families and 52 genera, which were being used for treating the different common kinds of ailments, pain, vomiting and also leprosy by the local and rural communities of Aligarh district. The mode of administration of different plant species were presented here with their family and local name.
\end{abstract}

Copy Right, IJAR, 2016,. All rights reserved.

\section{Introduction:-}

From ancient times, the plants have been used as sources of medicines by the tribal or human being. The traditional medical knowledge of plants and their use by indigenous cultures are not only useful for conservation of cultural traditions, but also for community health care and drug development the present and future (Pei, 2001). The present paper relates to the traditional practice to the treatment of various diseases. A number of plant species were used in traditional medicine for getting the relief in pain like headache, ear ache, toothache, colic pain and in curing the other ailments such as eczema, dysuria, leprosy etc.

\section{Material and methods:-}

The ethnobotanical informations are gathered during regular field trips through interviews and discussions with herbal medicine practitioners locally called as "Vaidhya", "Hakim", "Kabiraj" and other experienced old men. While noting the information, every care is taken to record the local name of plants and their parts, method of drug preparation and their uses. The modes of application of the different plant species are different for the treatment of various diseases. Plant species are identified by using relevant flora (Duthie, 1903-1929). The ethnomedicinal uses of the plants are compared with available Scientific Literatures (Chantia, 2003), (Chaudhry et al. 2006), (Singh and Huidrom, 2013), (Kumar and Chauhan, 2005), (Ranganathan et al. 2012), (Upadhyay and Singh, 2005).

\section{Results and Discussions:-}

The ethnomedicinal information regarding treatment of various pain and some common diseases collected in the course of field study was presented in tabular form. 62 ethnomedicinal plant species belonging to 35 families and 52 genera were enumerated in the present work. 44 plant species and 18 plant species were used for single drug

Corresponding Author:- Yogendra singh.

Address:- Department of Botany, Divya Nand Vidyamandir Maha vidyalaya, Sandila, Hardoi. 
treatments and multidrug treatment respectively. All plant species had been arranged alphabetically with botanical name, family, vernacular name, parts used, disease and mode of use (Table-1). In the present study, out of 35 families, Euphorbiaceae was mostly used in the treatment of diseases and pain. Leaf constitute was the highest (30) of utilization followed by seed (13), root (12), whole plant (11), stem (9), flower (3) and bud (2).

\section{Conclusion:-}

The present study helped list out various ethnomedicinal plants. The paper provided here can be utilized to further studies on conservation and cultivation of ethnomedicinal plants. The youth should also be encouraged to learn the traditional medicinal knowledge to preserve it from being lost with the older generation. The present paper revealed the various mode of drug preparation related to 62 ethnomedicinal plant species.

Table-1:- Result of field survey

\begin{tabular}{|c|c|c|c|c|}
\hline $\begin{array}{l}\text { Botanical name/Family \& } \\
\text { local name }\end{array}$ & $\begin{array}{l}\text { Fls/Frts } \\
\text { Time }\end{array}$ & $\begin{array}{l}\text { Parts } \\
\text { used }\end{array}$ & Disease & Preparation and mode of use \\
\hline $\begin{array}{l}\text { Abrus precatorius L. } \\
\text { (Fabaceae), } \\
\text { "Ghumch". }\end{array}$ & $\begin{array}{l}\text { Aug-Sep/ } \\
\text { Sep-oct }\end{array}$ & Seed & Headache & $\begin{array}{l}\text { Seed powder is sniffed for getting relief in } \\
\text { headache. }\end{array}$ \\
\hline $\begin{array}{l}\text { Acalypha indica L. } \\
\text { (Euphorbiaceae), } \\
\text { "Kuppi". }\end{array}$ & Sep/Feb & Leaf & $\begin{array}{l}\text { Eczema } \\
\text { Headache }\end{array}$ & $\begin{array}{l}\text { Fresh leaf extract addition with a little common } \\
\text { salt is applied externally on the affected part of } \\
\text { the body in case of eczema. } \\
\text { A piece of cotton is saturated with expressed } \\
\text { leaf juice and inserted into each nostril, } \\
\text { relieving head symptoms in congestive } \\
\text { headache. }\end{array}$ \\
\hline $\begin{array}{l}\text { Achyranthus aspera } \mathrm{L} \text {. } \\
\text { (Amaranthaceae), } \\
\text { "Chirchitta". }\end{array}$ & $\begin{array}{l}\text { Through } \\
\text { out of } \\
\text { year }\end{array}$ & Whole & $\begin{array}{l}\text { Headache } \\
\text { Ear ache } \\
\text { Toothache }\end{array}$ & $\begin{array}{l}\text { Whole plant is ground to make into a paste and } \\
\text { applied on the forehead at the time of } \\
\text { headache due to cold. } \\
\text { Whole plant is burnt to get the ash. The ash } \\
\text { mixed with sesamum oil is applied as ear drops } \\
\text { in the treatment of ear problems. } \\
\text { Leaves or roots are chewed gently in the cases } \\
\text { of toothache to remove the pain. }\end{array}$ \\
\hline $\begin{array}{l}\text { Adhatoda vasica Nees. } \\
\text { (Acanthaceae), } \\
\text { "Piyabans". }\end{array}$ & $\begin{array}{l}\text { Oct-Jan/ } \\
\text { Jan-Mar }\end{array}$ & Leaf & Vomiting & $\begin{array}{l}\text { Fresh flowers are boiled in little water to make } \\
\text { a decoction. It is given orally once a day to } \\
\text { cure vomiting. }\end{array}$ \\
\hline $\begin{array}{l}\text { Adina cordifolia Hook.f. } \\
\text { (Rubiaceae), } \\
\text { "Hald". }\end{array}$ & Jun-Oct & Buds & Headache & $\begin{array}{l}\text { Small buds ground with black pepper are } \\
\text { sniffed into the nose in severe headache. }\end{array}$ \\
\hline $\begin{array}{l}\text { Aegle marmelos Hook. F. } \\
\text { (Rutaceae) } \\
\text { "Bel Patther". }\end{array}$ & $\begin{array}{l}\text { Apr-May/ } \\
\text { May-July }\end{array}$ & Root & Ear ache & $\begin{array}{l}\text { Root is being used as a home remedy for } \\
\text { curing ear problems such as ear ache. The stiff } \\
\text { piece of root is dipped in Neem oil (seed oil of } \\
\text { Azadirachta indica ) and burn end. The oil that } \\
\text { drips from the burning end is applied into the } \\
\text { ear as an ear drops. }\end{array}$ \\
\hline $\begin{array}{l}\text { Albizzia labback L. } \\
\text { (Mimosaceae), } \\
\text { "Siras". }\end{array}$ & Apr-Jane & Bark & Toothache & $\begin{array}{l}\text { Bark decoction }(50-100 \mathrm{ml}) \text { is being used in } \\
\text { gargling to treat the toothache and gum ache. }\end{array}$ \\
\hline $\begin{array}{l}\text { Allium cepa } \mathrm{L} . \\
\text { (Liliaceae), } \\
\text { "Piyaj". }\end{array}$ & May-June & Bulb & Ear ache & $\begin{array}{l}\text { Bulb extract obtained by heating and squeezing } \\
\text { is applied into ear for earache. }\end{array}$ \\
\hline $\begin{array}{l}\text { Allium sativum } \mathrm{L} . \\
\text { (Liliaceae), } \\
\text { "Lahsun". }\end{array}$ & & Bulb & Eczema & $\begin{array}{l}\text { Bublets are crushed to make paste, which is } \\
\text { placed over the eczema twice a day. }\end{array}$ \\
\hline $\begin{array}{l}\text { Alstonia scholaris } \mathrm{L} \text {. } \\
\text { (Apocynaceae), }\end{array}$ & Winter & Bark & Colic pain, & $\begin{array}{l}\text { Bark is ground with water is strained off and } \\
\text { some of the bark decoction is given to patient }\end{array}$ \\
\hline
\end{tabular}




\begin{tabular}{|c|c|c|c|c|}
\hline "Chitwan". & & Whole & Ear ache & $\begin{array}{l}\text { and residue is rubbed over the pit of abdomen } \\
\text { for colic pain. } \\
\text { Plant juice mixed with the mustard oil is } \\
\text { boiled. The lukewarm extract is applied into } \\
\text { ear in case of earache as ear drops. }\end{array}$ \\
\hline $\begin{array}{l}\text { Amaranthus spinosus L. } \\
\text { (Amaranthaceae), } \\
\text { "Kanta chouli". }\end{array}$ & Aug-Jan & Root & Eczema & $\begin{array}{l}\text { Roots ground in water are applied externally on } \\
\text { eczematous skin. }\end{array}$ \\
\hline $\begin{array}{l}\text { Anethum graveolens L. } \\
\text { (Apiaceae), } \\
\text { "Sowa". }\end{array}$ & Winter & Seed & Ear ache & $\begin{array}{l}\text { 1-3 drops of the seed oil is applied into ear as a } \\
\text { good remedy for earache. }\end{array}$ \\
\hline $\begin{array}{l}\text { Argemone mexicana L. } \\
\text { (Papaveraceae), } \\
\text { "Satyanasi". }\end{array}$ & \begin{tabular}{|l|} 
Oct-Apr/ \\
Apr-May
\end{tabular} & Whole & Leprosy & $\begin{array}{l}\text { Plant extract is being used to cure leprosy and } \\
\text { it is also useful as blood purifier. }\end{array}$ \\
\hline $\begin{array}{l}\text { Azadirachta indica A.Juss. } \\
\text { (Meliaceae), } \\
\text { "Neem". }\end{array}$ & $\begin{array}{l}\text { Mar-May/ } \\
\text { May-June }\end{array}$ & $\begin{array}{l}\text { Leaf } \\
\text { Leaf \& } \\
\text { Flower } \\
\text { Stem } \\
\text { Bark }\end{array}$ & $\begin{array}{l}\text { Eczema } \\
\text { Leprosy } \\
\text { Toothache } \\
\text { Vomiting }\end{array}$ & $\begin{array}{l}\text { Leaf extract is applied externally over the body } \\
\text { in the case of eczema. } \\
\text { Leaves and flowers are crushed in equal } \\
\text { quantity of each. This is given orally to cure } \\
\text { leprosy. } \\
\text { Twig is being used as a toothbrush to cure the } \\
\text { toothache and gum problems. } \\
\text { Bark juice is given orally mixing with little } \\
\text { black salt and honey to allay the vomiting. }\end{array}$ \\
\hline $\begin{array}{l}\text { Bacopa monnieri L. } \\
\text { (Scrophuliaceae), } \\
\text { "Vermin". }\end{array}$ & $\begin{array}{l}\text { Aug-Oct/ } \\
\text { Oct-Nov }\end{array}$ & Leaf & Dysuria & $\begin{array}{l}\text { Leaf juice mixed with seed powder of } \\
\text { Cumminum cyminum and mishri (sugar candy) } \\
\text { is given while the soaked cloth in its juice is } \\
\text { kept on the navel in case of Dysuria. }\end{array}$ \\
\hline $\begin{array}{l}\text { Barleria prionitis } \mathrm{L} . \\
\text { (Acanthaceae), } \\
\text { "Katsareya". }\end{array}$ & $\begin{array}{l}\text { Oct-Feb/ } \\
\text { Mar-Apr }\end{array}$ & Leaf & Colic pain & $\begin{array}{l}\text { Whole plant (About half } \mathrm{kg} \text { ) is kept in one liter } \\
\text { of cold water for } 5-6 \text { days. The filtrate is } \\
\text { given in the dose of } 5 \mathrm{ml} \text {. twice a day for a } \\
\text { week in case of colic pain. }\end{array}$ \\
\hline $\begin{array}{l}\text { Boerhavia diffusa L. } \\
\text { (Nyctaginaceae), } \\
\text { "Santh". }\end{array}$ & $\begin{array}{l}\text { Most } \\
\text { Months }\end{array}$ & $\begin{array}{l}\text { Leaf \& } \\
\text { Stem } \\
\text { Seed }\end{array}$ & Vomiting & $\begin{array}{l}\text { Fresh stem and leaves are pounded to make } \\
\text { into a paste. This paste is applied to the } \\
\text { infected part daily for } 3-4 \text { weeks, for the } \\
\text { treatment of eczema. } \\
\text { About } 6 \text { gram seed powder is given orally to } \\
\text { allay the vomiting. }\end{array}$ \\
\hline $\begin{array}{l}\text { Brassica compestris } \mathrm{L} . \\
\text { (Brassicaceae), } \\
\text { "Sarson". }\end{array}$ & Nov-Dec & Seed & Ear ache & $\begin{array}{l}\text { Some lukewarm oil drops of seed are applied } \\
\text { into the ear for curing ear ache. }\end{array}$ \\
\hline $\begin{array}{l}\text { Calotropis procera Ait. } \\
\text { (Asclepiadaceae), } \\
\text { "Aak". }\end{array}$ & $\begin{array}{l}\text { Dec-Apr/ } \\
\text { May-Jun }\end{array}$ & $\begin{array}{l}\text { Root \& } \\
\text { Latex } \\
\text { Root }\end{array}$ & $\begin{array}{l}\text { Leprosy, } \\
\text { Toothache }\end{array}$ & $\begin{array}{l}\text { Root and dried milk sap (latex) is being used in } \\
\text { small doses in leprosy. } \\
\text { Fresh root is being used as toothbrush to cure } \\
\text { toothache. }\end{array}$ \\
\hline $\begin{array}{l}\text { Cannabis sativa } \mathrm{L} \text {. } \\
\text { (Cannabinaceae), } \\
\text { "Bhang". }\end{array}$ & Feb-Apr & Leaf & Eczema & $\begin{array}{l}\text { Aqueous paste of fresh leaves is applied on the } \\
\text { affected portion to cure eczema. }\end{array}$ \\
\hline $\begin{array}{l}\text { Capparis decidua Forsk. } \\
\text { (Capparidaceae), } \\
\text { "Karil". }\end{array}$ & $\begin{array}{l}\text { Mar-Jun/ } \\
\text { Jun-July }\end{array}$ & $\begin{array}{l}\text { Leaf \& } \\
\text { Buds }\end{array}$ & Toothache & $\begin{array}{l}\text { Buds and new born leaves are chewed in the } \\
\text { cases of toothache. }\end{array}$ \\
\hline $\begin{array}{l}\text { Cassia fistula } \mathrm{L} . \\
\text { (Caesalpiniaceae), } \\
\text { "Amaltas". }\end{array}$ & $\begin{array}{l}\text { Apr-Jun/ } \\
\text { Aug-Sep }\end{array}$ & $\begin{array}{l}\text { Leaf } \\
\text { Root }\end{array}$ & $\begin{array}{l}\text { Headache, } \\
\text { Headache }\end{array}$ & $\begin{array}{l}\text { Leaf paste is applied externally on the forehead } \\
\text { to relief in headache. } \\
\text { Root (without bark) is washed and pounded } \\
\text { mixed with black pepper. The juice of the } \\
\text { mixture is dropped into the nostril to cure }\end{array}$ \\
\hline
\end{tabular}




\begin{tabular}{|c|c|c|c|c|}
\hline & & & & headache. \\
\hline $\begin{array}{l}\text { Cassia tora } \mathrm{L} . \\
\text { (Caesalpiniaceae), } \\
\text { "Panwar". }\end{array}$ & $\begin{array}{l}\text { Aug-Oct/ } \\
\text { Oct-Nov }\end{array}$ & Seed & Leprosy & $\begin{array}{l}\text { Seeds decomposed in curd are ground in lemon } \\
\text { juice and lapped on leprosy. Leaf juice (5- } \\
10 \mathrm{ml} \text {.) is also given orally during treatment. }\end{array}$ \\
\hline $\begin{array}{l}\text { Cichorium intybus L. } \\
\text { (Asteraceae), } \\
\text { "Kashni". }\end{array}$ & Jan-Apr/ & Leaf & Headache & $\begin{array}{l}\text { Leaf paste is applied externally on the forehead } \\
\text { to get relief in headache. }\end{array}$ \\
\hline $\begin{array}{l}\text { Commelina benghalensis } \mathrm{L} \text {. } \\
\text { (Commelinaceae), } \\
\text { "Kankaua". }\end{array}$ & \begin{tabular}{|l|} 
July-Oct/ \\
Oct-Nov
\end{tabular} & Whole & leprosy & $\begin{array}{l}\text { Entire plant sap is applied on the skin eruptions } \\
\text { such as leprosy. }\end{array}$ \\
\hline $\begin{array}{l}\text { Coriandrum sativum } \mathrm{L} . \\
\text { (Apiaceae), } \\
\text { "Dhania". }\end{array}$ & Jan-Mar & Seed & Vomiting & $\begin{array}{l}\text { Seed (250gram) is boiled with the plant of } \\
\text { Tribulus terristris (Gokhru, 250) in water ( } \\
\text { liters) until it is remained } 1 \text { litre. After } \\
\text { filtration, the extract is mixed with } 250 \text { gram } \\
\text { ghee. The mixture (6gram) is given along with } \\
\text { a cup of milk in the morning daily in case of } \\
\text { dysuria. } \\
10 \text { gram seed crushed with water and sugar is } \\
\text { given to allay the vomiting. }\end{array}$ \\
\hline $\begin{array}{l}\text { Cucumis melo var. agrestis } \\
\text { Naud. } \\
\text { (Cucurbitaceae), } \\
\text { "Sainda". }\end{array}$ & \begin{tabular}{|l} 
Jul-Aug/ \\
Aug-Sep
\end{tabular} & Seed & Dysuria & $\begin{array}{l}\text { Seed powder is useful in painful discharge and } \\
\text { suppression of urine. }\end{array}$ \\
\hline $\begin{array}{l}\text { Datura metel L. } \\
\text { (Solanaceae), } \\
\text { "Dhatura". }\end{array}$ & Nov-Feb & Leaf & Eczema & $\begin{array}{l}\text { Leaves crushed in latex of Euphorbia noriifolia } \\
\text { and Calotropis procera is mixed with urine of } \\
\text { cow. The extract is very useful externally in } \\
\text { curing the eczema. }\end{array}$ \\
\hline $\begin{array}{l}\text { Eclipta prostrata } \mathrm{L} . \\
\text { (Asteraceae), } \\
\text { "Kala Bhangra". }\end{array}$ & $\begin{array}{l}\text { Most part } \\
\text { of year }\end{array}$ & Whole & $\begin{array}{l}\text { Eczema, } \\
\text { Headache }\end{array}$ & $\begin{array}{l}\text { Plant juice }(5 \text { grams }) \text { mixed with } 50 \mathrm{ml} \text { milk } \\
\text { and some sugar is given twice a day for } 8 \text { days } \\
\text { to the patient suffering from eczema. } \\
\text { Fresh plant juice mixing with a little sesamum } \\
\text { oil is applied on the forehead for headache. }\end{array}$ \\
\hline $\begin{array}{l}\text { Euphorbia hirta L. } \\
\text { (Euphorbiaceae), } \\
\text { "Dugdhi". }\end{array}$ & $\begin{array}{l}\text { Most } \\
\text { parts } \\
\text { of year }\end{array}$ & Whole & Vomiting & Plant juice is given orally to allay vomiting. \\
\hline $\begin{array}{l}\text { Euphorbia neriifolia L. } \\
\text { (Euphorbiaceae), } \\
\text { "Senhar". }\end{array}$ & $\begin{array}{l}\text { Nov-Jan/ } \\
\text { Jan-Mar }\end{array}$ & $\begin{array}{l}\text { Stem } \\
\text { latex }\end{array}$ & Dysuria, & $\begin{array}{l}\text { Latex mixed with flour of gram (Cicer } \\
\text { arietinum) is made into small pills in dysuria. }\end{array}$ \\
\hline $\begin{array}{l}\text { Euphorbia prostrata Sims. } \\
\text { (Euphorbiaceae), } \\
\text { "Gonemchi". }\end{array}$ & $\begin{array}{l}\text { Most part } \\
\text { of year }\end{array}$ & Whole & Eczema & $\begin{array}{l}20 \text { gram plant is ground and mixed with } 10 \\
\text { gram butter. This material is applied on the } \\
\text { affected part in the cases of eczema. After } 3-4 \\
\text { hours, it is washed with water. This treatment } \\
\text { should be continued for some days. }\end{array}$ \\
\hline $\begin{array}{l}\text { Ficus benghalensis L. } \\
\text { (Moraceae), } \\
\text { "Bargad". }\end{array}$ & Mar-Jun & Root & Toothache & $\begin{array}{l}\text { Milk juice of aerial root is good remedy for } \\
\text { toothache. }\end{array}$ \\
\hline $\begin{array}{l}\text { Ficus religiosa } \mathrm{L} \text {. } \\
\text { (Moraceae), } \\
\text { "Pipal". }\end{array}$ & Mar-May & Leaf & Vomiting & $\begin{array}{l}\text { Old leaves of Ficus religiosa soaked in water, } \\
\text { is being used orally to allay the vomiting. }\end{array}$ \\
\hline $\begin{array}{l}\text { Foeniculum vulgare Mill. } \\
\text { (Apiaceae), } \\
\text { "Sounf". }\end{array}$ & $\begin{array}{l}\text { Jan-Feb/ } \\
\text { Feb-Mar }\end{array}$ & $\begin{array}{l}\text { Seed } \\
\text { Whole }\end{array}$ & $\begin{array}{l}\text { Dysuria } \\
\text { Colic pain }\end{array}$ & $\begin{array}{l}\text { Seed decoction of Foeniculum vulgare kept } \\
\text { into the batasha (a spongy cake of sugar) is } \\
\text { given orally for some days in dysuria. } \\
\text { A constituent liquorices powder of whole plant } \\
\text { is being used for allaying griping in stomach in } \\
\text { case of colic pain. }\end{array}$ \\
\hline
\end{tabular}




\begin{tabular}{|c|c|c|c|c|}
\hline $\begin{array}{l}\text { Heliotropium eichwaldi } \\
\text { Steud. } \\
\text { (Boraginaceae), } \\
\text { "Kadhera". }\end{array}$ & $\begin{array}{l}\text { Dec-Apr/ } \\
\text { Apr-May }\end{array}$ & Leaf & Ear ache & $\begin{array}{l}\text { Some drops of leaf extract are applied into the } \\
\text { ear to cure ear ache. }\end{array}$ \\
\hline $\begin{array}{l}\text { Holoptelea integrifolia } \\
\text { (Roxb.) Planch. } \\
\text { (Ulmaceae), } \\
\text { "Papri". }\end{array}$ & Fab-Apr & Leaf & Leprosy & $\begin{array}{l}\text { Leaf extracts (100 grams) is given orally daily } \\
\text { in case of leprosy. }\end{array}$ \\
\hline $\begin{array}{l}\text { Jatropha gossypifolia } \mathrm{L} \text {. } \\
\text { (Euphorbiaceae), } \\
\text { "Verenda". }\end{array}$ & $\begin{array}{l}\text { Aug-Sep/ } \\
\text { Sep-Oct }\end{array}$ & Stem & Headache & $\begin{array}{l}\text { Stem extract is squeezed into the nostrils, } \\
\text { causing the patient sneeze and effectively } \\
\text { curing headache. }\end{array}$ \\
\hline $\begin{array}{l}\text { Melia azedarach } \mathrm{L} . \\
\text { (Miliaceae), } \\
\text { "Bukain". }\end{array}$ & $\begin{array}{l}\text { Mar-Apr/ } \\
\text { Apr-Jun }\end{array}$ & $\begin{array}{l}\text { Leaf \& } \\
\text { Flower } \\
\text { Leaf \& } \\
\text { Bark } \\
\end{array}$ & $\begin{array}{l}\text { Headache } \\
\text { Leprosy }\end{array}$ & $\begin{array}{l}\text { Flower and leaves are applied externally on the } \\
\text { forehead as a poultice to relive nervous } \\
\text { headache. } \\
\text { Leaves and stem bark is being used internally } \\
\text { and also externally to leprosy patients }\end{array}$ \\
\hline $\begin{array}{l}\text { Mentha piperita } \mathrm{L} . \\
\text { (Lamiaceae), } \\
\text { "Peperment". }\end{array}$ & $\begin{array}{l}\text { Oct-Nov/ } \\
\text { Nov-Dec }\end{array}$ & $\begin{array}{l}\text { Leaf } \\
\text { Whole }\end{array}$ & $\begin{array}{l}\text { Toothache, } \\
\text { Colic pain }\end{array}$ & $\begin{array}{l}\text { Leaves are chewed for the treatment of } \\
\text { toothache. } \\
\text { A hot herb infusion is given as tea, soothes } \\
\text { colic pain. }\end{array}$ \\
\hline $\begin{array}{l}\text { Mentha spicata } \mathrm{L} . \\
\text { (Lamiaceae), } \\
\text { "Jangli Podina". }\end{array}$ & $\begin{array}{l}\text { Oct-Nov/ } \\
\text { Nov-Dec }\end{array}$ & Leaf & Vomiting & $\begin{array}{l}\text { Sauce prepared by mixing the leaves with some } \\
\text { black pepper and black salt is given in } \\
\text { condition of anorexia and also to allay the } \\
\text { vomiting. } \\
\text { Sweetened infusion of leaf is made by mixing } \\
\text { with some drops of honey, given as a remedy } \\
\text { to allay vomiting at the time of pregnancy. }\end{array}$ \\
\hline $\begin{array}{l}\text { Mimusops elengi } \mathrm{L} \text {. } \\
\text { (Sapotaceae), } \\
\text { "Maulsari". }\end{array}$ & $\begin{array}{l}\text { Apr-May/ } \\
\text { May-Jun }\end{array}$ & Flower & Headache & $\begin{array}{l}\text { Powder of the dry flowers snuffed gives relief } \\
\text { in case of headache after some time. }\end{array}$ \\
\hline $\begin{array}{l}\text { Mucuna pruriens L. } \\
\text { (Fabaceae), } \\
\text { "Konch". }\end{array}$ & $\begin{array}{l}\text { Aug-Oct/ } \\
\text { Oct-Nov }\end{array}$ & Root & Dysuria & $\begin{array}{l}\text { Root decoction }(50-100 \mathrm{ml}) \text { is given to the } \\
\text { patient for curing dysuria and other kidney } \\
\text { diseases }\end{array}$ \\
\hline $\begin{array}{l}\text { Nerium indicum Mill. } \\
\text { (Apocynaceae), } \\
\text { "Kanner". }\end{array}$ & \begin{tabular}{|l|} 
Jun-Jul/ \\
Jul-Sep
\end{tabular} & $\begin{array}{l}\text { Leaf } \\
\text { Root } \\
\text { Seed }\end{array}$ & $\begin{array}{l}\text { Headache, } \\
\text { Leprosy, } \\
\text { Colic pain }\end{array}$ & $\begin{array}{l}\text { Snuff prepared from dry leaves is being used to } \\
\text { cure headache. } \\
\text { Root oil mixed with seed oil of Dalbergia } \\
\text { sissoo is applied externally to leprosy patient } \\
\text { to get relief. } \\
\text { Seed or the root bark sap ( } 60 \mathrm{mg}) \text { is applied } \\
\text { externally on the abdomen as an ointment to } \\
\text { get relief in colic pain. }\end{array}$ \\
\hline $\begin{array}{l}\text { Ocimum basilicum } \mathrm{L} . \\
\text { (Lamiaceae), } \\
\text { "Kali Tulsi". }\end{array}$ & \begin{tabular}{|l} 
Nov-Dec/ \\
Dec-Jan
\end{tabular} & Leaf & $\begin{array}{l}\text { Toothache, } \\
\text { Eczema }\end{array}$ & $\begin{array}{l}\text { When the leaves are chewed, they are very } \\
\text { useful to remove the toothache. } \\
\text { The paste prepared by equal leaf quantities of } \\
\text { Ocimum basilicum and Psidium guajava is } \\
\text { externally used over the infected portion for a } \\
\text { few days. }\end{array}$ \\
\hline $\begin{array}{l}\text { Ocimum sanctum } \mathrm{L} \text {. } \\
\text { (Lamiaceae), } \\
\text { "Tulsi". }\end{array}$ & $\begin{array}{l}\text { Nov-Dec/ } \\
\text { Dec-Jan }\end{array}$ & Seed & Dysuria & $\begin{array}{l}\text { Seeds soaked in water is taken with sugar, } \\
\text { relieves urinary complaints such as dysuria. }\end{array}$ \\
\hline $\begin{array}{l}\text { Oxalis corniculata } \mathrm{L} . \\
\text { (Oxalidaceae), } \\
\text { "Khatti Mithi". }\end{array}$ & \begin{tabular}{|l} 
Dec-Feb/ \\
Feb-Apr
\end{tabular} & $\begin{array}{l}\text { Whole } \\
\text { Leaf }\end{array}$ & $\begin{array}{l}\text { Headache, } \\
\text { Colic pain }\end{array}$ & $\begin{array}{l}\text { Plant paste is massaged on the forehead for } \\
\text { getting the relief in headache. } \\
\text { Leaf decoction added some roasted hing } \\
\text { (Asafoetida) is given orally to the patient in } \\
\text { case of colic pain. }\end{array}$ \\
\hline
\end{tabular}




\begin{tabular}{|c|c|c|c|c|}
\hline $\begin{array}{l}\text { Plumbago zeylanica L. } \\
\text { (Plumbaginaceae), } \\
\text { "Chirchitta". }\end{array}$ & $\begin{array}{l}\text { Oct-Jan/ } \\
\text { Jan-Feb }\end{array}$ & Bark & Eczema & $\begin{array}{l}\text { Bark Powder mixed with two times of butter is } \\
\text { kept in copper bowl. This bowl is kept into } \\
\text { sunlight for } 5 \text { hours. This melting butter is } \\
\text { applied externally for a long time to remove } \\
\text { eczema. } \\
\text { Root paste prepared by mixing with milk, } \\
\text { vinegar or salt and water is being used as an } \\
\text { external application in leprosy. }\end{array}$ \\
\hline $\begin{array}{l}\text { Polygonum glabrum Hook.f. } \\
\text { (Polygonaceae), }\end{array}$ & $\begin{array}{l}\text { Oct-Dec/ } \\
\text { Dec-Jan }\end{array}$ & Leaf & Colic pain & $\begin{array}{l}\text { Leaf infusion is given orally to the patients to } \\
\text { get relief in colic pain. }\end{array}$ \\
\hline $\begin{array}{l}\text { Polygonum plebeium R.Br. } \\
\text { (Polygonaceae), } \\
\text { "Machechi". }\end{array}$ & $\begin{array}{l}\text { Most of } \\
\text { the year }\end{array}$ & Whole & Colic pain & $\begin{array}{l}\text { Whole plant is crushed with about } 500 \mathrm{ml} \\
\text { water and gently heated for } 5-10 \text { minutes. } \\
\text { The decoction is given twice a day to treat } \\
\text { bowel complaints (such as colic pain). }\end{array}$ \\
\hline $\begin{array}{l}\text { Pongamia pinnata }(\mathrm{L} .) \\
\text { Pierra. } \\
\text { (Fabaceae), } \\
\text { "Karanz". }\end{array}$ & $\begin{array}{l}\text { Mar-May/ } \\
\text { May-Jun }\end{array}$ & Leaf & Eczema & $\begin{array}{l}\text { Leaves juice is applied externally over affected } \\
\text { part of the body to cure eczema. }\end{array}$ \\
\hline $\begin{array}{l}\text { Psidium guajava } \mathrm{L} . \\
\text { (Myrtaceae), } \\
\text { "Amroud" }\end{array}$ & May-Jul & Leaf & Toothache & $\begin{array}{l}\text { Leaf decoction is being used as gargle to relief } \\
\text { in toothache. It is also useful in gum boils. }\end{array}$ \\
\hline $\begin{array}{l}\text { Ranunculus scleratus L. } \\
\text { (Ranunculaceae), } \\
\text { "Jal Dhania". }\end{array}$ & $\begin{array}{l}\text { Jan-May/ } \\
\text { May-Jun }\end{array}$ & Leaf & Toothache & $\begin{array}{l}\text { Leaf pulp made into a little of wine is applied } \\
\text { on teeth to relieve pain. }\end{array}$ \\
\hline $\begin{array}{l}\text { Ricinus communis L. } \\
\text { (Euphorbiaceae), } \\
\text { "Arund". }\end{array}$ & & Seed & Headache & $\begin{array}{l}\text { Seed oil is lapped externally on forehead as a } \\
\text { massage cream in severe headache. }\end{array}$ \\
\hline $\begin{array}{l}\text { Sesbania sesban (L.) Merr. } \\
\text { (Fabaceae), } \\
\text { "August". }\end{array}$ & Sep-Oct & Root & Leprosy & $\begin{array}{l}\text { Root juice }(10-20 \mathrm{ml} .) \text { is given to the patient } \\
\text { along with milk in leprosy. }\end{array}$ \\
\hline $\begin{array}{l}\text { Sisymbrium irio L. } \\
\text { (Brassicaceae), } \\
\text { "Khumbkalan". }\end{array}$ & Mar-Apr & Seed & Vomiting & $\begin{array}{l}\text { Seed decoction }(8-10 \mathrm{ml}) \text { is given orally to } \\
\text { allay diarrhoea and vomiting in cases of } \\
\text { cholera. }\end{array}$ \\
\hline $\begin{array}{l}\text { Solanum indicum } \mathrm{L} \text {. } \\
\text { (Solanaceae), } \\
\text { "Terri Baigan". }\end{array}$ & $\begin{array}{l}\text { Aug-Oct/ } \\
\text { Oct-Nov }\end{array}$ & $\begin{array}{l}\text { Fruit } \\
\text { Leaf }\end{array}$ & $\begin{array}{l}\text { Vomiting, } \\
\text { Vomiting }\end{array}$ & $\begin{array}{l}\text { Fruit juice admixing with ghee and honey is } \\
\text { given to allay the vomiting. } \\
\text { Leaf juice mixed with little ginger powder is } \\
\text { administered to stop vomiting. }\end{array}$ \\
\hline $\begin{array}{l}\text { Solanum nigrum L. } \\
\text { (Solanaceae), } \\
\text { "Makoi". }\end{array}$ & $\begin{array}{l}\text { Oct-Jan/ } \\
\text { Jan-Mar }\end{array}$ & Leaf & Colic pain & $\begin{array}{l}\text { Three teaspoonfuls leaf extract is given twice } \\
\text { daily for } 3-5 \text { days to cure colic pain. }\end{array}$ \\
\hline $\begin{array}{l}\text { Solanum xanthocarpum } \\
\text { Schrad. } \\
\text { (Solanaceae), } \\
\text { "Kateri". }\end{array}$ & $\begin{array}{l}\text { May-Aug/ } \\
\text { Aug-Sep }\end{array}$ & Seed & Vomiting & $\begin{array}{l}\text { Past (prepared by the mixing of seed paste of } \\
\text { Solanum xanthocarpum and bulb paste of } \\
\text { Allium cepa) is being used externally as a cure } \\
\text { for toothache. } \\
\text { Root is pounded and mixed with some wine is } \\
\text { given for checking the vomiting. }\end{array}$ \\
\hline $\begin{array}{l}\text { Terminalia arjuna Roxb. } \\
\text { (Combretaceae), } \\
\text { "Arjun". }\end{array}$ & $\begin{array}{l}\text { May-Jun/ } \\
\text { Jul-Aug }\end{array}$ & Leaf & Ear ache & $\begin{array}{l}\text { Leaf juice is used as ear drops to remove the } \\
\text { pain. }\end{array}$ \\
\hline $\begin{array}{l}\text { Tribulus terrestris L. } \\
\text { (Zygophyllaceae), } \\
\text { "Gokhru". }\end{array}$ & $\begin{array}{l}\text { Jul-Sep/ } \\
\text { Sep-Nov }\end{array}$ & Fruit & Dysuria & $\begin{array}{l}\text { Fruit power ( } 3-6 \text { gram) is given thrice a day in } \\
\text { dysuria. }\end{array}$ \\
\hline $\begin{array}{l}\text { Vernonia cinerea } \mathrm{L} . \\
\text { (Asteraceae), } \\
\text { "Phulni". }\end{array}$ & $\begin{array}{l}\text { Sep-Feb/ } \\
\text { Feb-Mar }\end{array}$ & Root & Colic pain & $\begin{array}{l}\text { Root juice }(10-20 \mathrm{ml}) \text { is given orally to cure } \\
\text { cold, cough and also colic pain. }\end{array}$ \\
\hline
\end{tabular}




\section{Acknowledgement:-}

The author is thankful to the practitioners and other experienced old men. I would like to thank my best friend Dr. Salendra kumar for suggesting the problem and for incessant help and exquisite guidance. Their tireless efforts, immense patience, motivation and lively discussion throughout the course of present investigation, made working with them an enjoyable experience.

\section{References:-}

1. Alam, M. M. and Anis, M. (1987): Ethnomedicinal uses of plants growing in the Bulandshahr district of Northern India. J.Ethnopharmacology, 19: 85-88.

2. Chantia, A. (2003): Traditional knowledge of ethnomedicine in Jaunsar-Bawar, Dehradun district, India. J. Trad. Knowledge. 2 (4): 397-399.

3. Chaudhry, B. L., Bhagora, F.S. and Khichio, Y. S. (2006): Medicinal plants used by tribals of Banswara district (Raj.), India. Indian J. Appl. Pure Biol. 21 (2): 317-320.

4. Duthie, J. F. (1903-1929): Flora of the upper gangetic plain of the adjacent Siwalik and Sub-Himalayan tracts, Clacutta. 3th volume.

5. Kumar, S. and Chauhan, A. K. S. (2005): Some ethnomedicinal plantlores from Bharatpur district of Rajasthan. J. Econ. Taxon. Bot. 29 (4): 733-737.

6. Pei, S. J. (2001): Ethnobotanical approaches of traditional medicine studies: some experiences from Asia. Pharmaceut. Biol. 39: 74-79.

7. Ranganathan, R., Vijayalakshmi, R. and Parameswari, P. (2012): Ethnomedicinal survey of Jawadhu hills in Tamil Nadu. Asian jouranal of pharmaceutical and clinical research. Vol 5: suppl 2. ISSN 0974-2441.

8. Singh, K. J. and Huidrom, D. (2013): Ethnobotanical uses of medicinal plant, Justicia adhatoda L. by Meitei community of Manipur, India Journal of Coastal Life Medicine 2013. 1(4): 322-325.

9. Upadhyay, R. and Singh, J. (2005): Ethnomedicinal uses of plants from Tikri forest of Gonda district (U.P.). Ethnobotany. 17 (1-2): 167-170. 